This is the accepted version of an article published by Sage in Environment and Planning D: Society and Space Vol. 34 (4), 583-600. Published version available from: https://doi.org/10.1177/0263775815623538

Accepted version downloaded from SOAS Research Online: http://eprints.soas.ac.uk/22575/ under licence CC-BYNC 4.0 International

The Politics of Pleasure: Promenading on the Corniche and Beachgoing ${ }^{1}$

This is the aim of my explorations: examining the traces of happiness still to be glimpsed, I gauge its short supply. If you want to know how much darkness there is around you, you must sharpen your eyes, peering at the faint lights in the distance.

Italo Calvino, Invisible Cities

Laleh Khalili

Department of Politics and International Studies

SOAS University of London

Thornhaugh St, Russell Sq

London WC1H OXG

United Kingdom

+442078984735

Lk4@soas.ac.uk

The incongruity between the beach and the Corniche on the one hand and the Palestinian camps in southern Beirut on the other cannot be overstated. While the beach and the Corniche vibrate with the pleasures of open skies, coruscating waves, and human interaction, the camps are about constriction. Established on sandy grounds outside Beirut city limits in the years following Palestinian refugees' expulsion in 1948, Burj al-Barajna and Shatila are now concrete slums absorbed into the fabric of the city, dense, dark, and expanding vertically. Their narrow skies are criss-crossed with the dark tangle of electric wires, and their narrow alleyways flood in the rainy season. Shatila's border blur into the adjacent neighbourhoods while Burj al-Barajna's boundaries are ever encroached upon by the network of highways that now delimit its northern and western sides. The proximity of the buildings to each other across the cramped camp lanes means that what you do in your house can easily be seen and heard by your neighbours.

By contrast, you can fill your lungs with sultry sea air on the Corniche or at the beach. You can wander along the wide pavement of the Corniche and people-watch. You can smoke a shisha; you can rent a bicycle at the Corniche. You can chat and laugh, knowing that you are not observed or overheard. The "you" in this instance is a group of young women from the southern camps of Beirut. They are in their late teens and twenties. Some are students in universities or vocational training courses; others work for small businesses in the southern suburbs. Though they don't represent the majority of their age and gender cohort in the camps, they are nevertheless the harbingers of transformations taking place there. These transformations -resulting from legal and political shifts in the last decade- mean that Palestinians can now formally hold jobs and attend universities (if they can afford the fees). The income they earn is

\footnotetext{
${ }^{1}$ I am grateful to Palestine American Research Centre and the British Academy (SG121814) for funding the fieldwork. And for their generous and critical reading of earlier drafts, to Miriyam Aouragh, Brenna Bhandar, Nadeem Karkabi, Maya Mikdashi and Rahul Rao I give both my gratitude and my apologies for not taking onboard all their suggestions. The anonymous referees who read the paper for the journal have been extraordinary in their thoughtfulness, incisiveness of their critique and demand for theoretical and stylistic clarity.
} 
This is the accepted version of an article published by Sage in Environment and Planning D: Society and Space Vol. 34 (4), 583-600. Published version available from: https://doi.org/10.1177/0263775815623538

Accepted version downloaded from SOAS Research Online: http://eprints.soas.ac.uk/22575/ under licence CC-BYNC 4.0 International

mostly saved or shared with their families; but they also hold back a small amount for leisure spending. This meagre spending covers the cost of transport, the entry fees for the beach, and some foods or drinks.

This article argues against seeing these women's practices of leisure -especially in the context of ongoing struggles over recognition and against exploitation- as frivolous performances of consumerism or a betrayal of politics. Instead, I argue that, firstly, such practices of leisure are clear alternatives to the deadening grind of the world of work as these women are gradually extracted from a state of deproletarianised camp life into the world of wage labour. In other words, these moments of pleasure are caesuras in the massive apparatus of power-welded from strands of wage labour, nationalist certitudes, and political exclusion- which constricts these women. Further, these pleasurable practices don't have to be acts of resistance for them to be meaningful or necessary.

Second, I argue that what allows these pleasurable practices is the ability of these women to leave the spaces of the camp for places that are public, less surveilled, and marked by the convivial encounters of peoples across class, national, and gender boundaries. This conviviality happens in a context of tensions under the surface of Lebanon's skin, which accounts for its preciousness and fragility. Thus, this article is as much about the centrality of such spaces to public affects, however provisional and unstable the spaces' public-ness or conviviality.

The Palestinianness of these women matters to the argument: Palestinian refugees' relative lack of access to resources and public spaces; the specific histories of Palestinian presence in Lebanon; and their relative class position within Lebanon all matter. Perhaps most important is, however, the social transformations in this relative class position and changes in the way they live and work and their access to leisure.

Here, I describe what pleasure means in the context of young Palestinian lives in Beirut, sketch the theoretical debates in which this article is situated, provide an ethnographic reflection on how pleasure is political for these young Palestinian women, and finally reflect on the stakes of thinking about pleasure more broadly.

\section{The Definitions of Pleasure}

Is pleasure a thing of the psyche or of the social? Of embodied enjoyment, an expression of interiority, or something transcendental? And where is the politics in pleasure?

One of the most entrenched uses of "pleasure" as a psychic concept occurs in Freudian analyses of the "pleasure principle" and in the Lacanian reflections on jouissance or sexual pleasure (Freud, (1922)1955; Lacan 1981; Marcuse, (1956)1986). ${ }^{2}$ Although some of the public pleasures I discuss have a sensual (though not necessarily sexual) component, I conceptualise pleasure here as a more publicly-experienced affect, more akin to fun than to psychic and sexual experiences. Here I have followed the translator of Henri Lefebvre's Toward an Architecture of Enjoyment, who, listening to Lefebvre himself, argues that "jouissance" is a psychoanalytic term of art, and that the term “"enjoyment,' in spite of its humble workaday simplicity and lack of academic standing, has the virtue of reflecting such activity, one that is commonplace, easily accessible" and

\footnotetext{
${ }^{2}$ I also agree with Tim Dean's reading of Foucault on pleasure: “Reducing bodily pleasure to sexual pleasure serves to corral it within a scientia sexualis, where it once again becomes an index of truth and hence a means of regulation" (2012, page 479).
} 
This is the accepted version of an article published by Sage in Environment and Planning D: Society and Space Vol. 34 (4), 583-600. Published version available from: https://doi.org/10.1177/0263775815623538

Accepted version downloaded from SOAS Research Online: http://eprints.soas.ac.uk/22575/ under licence CC-BYNC 4.0 International

embodied, rather than "something abstract, much less purely psychoanalytical" (translator's note in Lefebvre, 2014, page x).

If Lacanian jouissance is inadequate to the task at hand, so are Anglophone concepts of pleasure or happiness rooted in liberal discussions of utility. Utilitarian understandings of felicity follow Jeremy Bentham in relating the management of desire and happiness to the administration of public wellbeing in modern welfare states. ${ }^{3}$ This utilitarian understanding has become embedded in a biopolitical apparatus of control, measurement and management. ${ }^{4} \mathrm{~A}$ broad range of feminist and queer theories have illuminated the complexities and complicities of "happiness" in the reinforcement of extant gendered, raced, and classed hierarchies and the maintenance of hegemony (Ahmed, 2010; Berlant, 2011a; 2011b).

Here I define pleasure as a "public feeling" generated in moments of convivial encounter. It exceeds the individual's psychic or corporeal enjoyments, and translates into the kind enjoyment that arises from collective practices. As such, the publicness of the feeling matters as much as its joyfulness. Precisely because of its collectivity, the pleasure of conviviality is about overcoming atomisation or individuation even if it does not sow transgression or resistance. This kind of conviviality is, in the context of histories and prospects of sectarian enmity and the banal but crushing grind of work life, a political promise -however utopian- of "a life held in common".

Though the practices of pleasure here occur during leisure activities, my arguments overlap only slightly with the scholarly literature on leisure, because much of the leisure literature either provides ways of "improving" leisure activities or sternly reject leisure as capitalist false consciousness. That said, here I will also be touching on some recent works that examine leisure activities and spaces in exciting and provocative ways (inter alia Deeb and Harb, 2014; Hazbun, 2008; 2010; Junka, 2006; Menoret, 2014).

\section{Swimming in the Sea, Cycling on the Corniche}

Approximately one summer weekend in every four, Hala, and two sisters, Sara and Sirene, ${ }^{5}$ gather up their shishas along with charcoal and tobacco, sandwiches and snacks and water bottles, and their towels and swimsuits, head out of the camp and catch a shared servees taxi heading south towards Saida. At Jiyeh, around 20 kilometres south of the camp, they alight and walk downhill towards Bellevue women-only beach resort. They usually arrive just as the resort is opening for the day and remain until closing time. On the way back, they catch one of the many minivans that wait outside the gates and head back to the camp in Beirut's southern suburbs. Many of the Beiruti beachgoers (and others from elsewhere in southern Lebanon or Shouf

\footnotetext{
${ }^{3}$ For example, see Bok 2010. For a history of happiness see McMahon, 2006.

${ }^{4}$ See Binkley, 2011 which critically examines the way happiness works as a technique of governmentality.

${ }^{5}$ These women's profiles here are composites of 8 different women with whom I conducted my research in Beirut. I have chosen to combine or blur certain details in order to protect their identities but also because delineating them individually would be too cumbersome. I draw on several episodes of participant observation over the course of two years (2012-2014) of intermittent research in Beirut during the summer months when leisure activities were most frequent. I have known my interlocutors for many years, as they are younger relatives of people I had met when I first lived in Burj al-Barajna camp in 2001-2002 while conducting research for an earlier book (Khalili, 2007). The women themselves are from Burj al-Barajna and Shatila camps. I chose these women because for me the transformation in their social status - as they graduated from university, became employed and earned an independent income- was indicative of larger changes taking place in the camps. Although no official or even informal statistics exist for the income profiles of Palestinians in the camp, my own observations indicate that the changes in employment laws have opened up opportunities for employment for many camp women.
} 
This is the accepted version of an article published by Sage in Environment and Planning D: Society and Space Vol. 34 (4), 583-600. Published version available from: https://doi.org/10.1177/0263775815623538

Accepted version downloaded from SOAS Research Online: http://eprints.soas.ac.uk/22575/ under licence CC-BYNC 4.0 International

Mountain towns) have driven here in their private cars, and the parking lot outside Bellevue beach is full of sturdy middle class cars, rather than more extravagant luxury vehicles.

Hala, Sara, and Sirene's mothers have worked for local NGOs in the camps since the end of the Lebanese Civil War. Both mothers started as clerical or care workers hired by NGOs providing disabled or child or elderly care, and over the course of the last twenty years, both women have become well-known not only where they work, but also by all foreign visitors to the camps, as welcoming and accessible hosts. The young women's fathers have had both legal and illegal jobs in Beirut, one as a chauffeur and the other as a skilled furniture-maker. Sara and Sirene's father also spent some time in the Gulf earning money as a chauffeur there. That these families survived on two salaries -however meagre by Lebanese standards- distinguishes them from the majority of other camp families that are dependent on aid or on menial informal jobs. But their income and lifestyles also distinguish them from the better-off camp families. The breadwinners of the camp middle class are often founders of NGOs or high officials of political parties and increasingly professional workers in the private sector in Lebanon. The incomes of these families are comparable to lower middle class Lebanese incomes, and once they can, these families move outside the camp, purchasing land or apartments in more affordable suburbs of Beirut. $^{6}$

What distinguishes Hala, Sara, and Sirene's generation from the preceding one is that they do not work in NGOs or aid organisations in the camp. Further, while in their parents' generation, the breadwinners were often the men in the family, in the young women's generation, anecdotal evidence suggests that young women tend to have better-paying jobs than their brothers (who often work in skilled and semi-skilled construction jobs). Hala attended Lebanese University while Sara went to Beirut Arab University; and they both have attained undergraduate degrees in professional and business-related fields (management, accounting, finance, etc.). Sirene plans to go when she finishes her baccalaureate. What has allowed them to have a university education is the hard graft of their parents and their double income. They have been able to find jobs (in the offices of small commercial and trade businesses) because of the 2010 changes in Lebanese labour laws pertaining to Palestinians. These laws have removed some -though not all- of the draconian restrictions on Palestinians working in Lebanon, though they still prevent Palestinians from working in medicine, engineering, law, real estate management, and accountancy. That said, Hala works as an accountant in a firm owned by a Shi'a family who trade with Iran. Hala and Sara work 5 days a week, and Hala, especially, keeps a very strict nine-to-five schedule, "not working a minute more than she has to." The weekends are their periods of leisure, and the beach is their most favourite pastime and the source of much of their excitement.

Like almost all Beirut waterfront, Bellevue Beach is privatised (Dictaphone, 2013; Sawalha, 2010; Zbeeb, 2012b). Concrete barriers extending into the sea block the beach from view, and walls topped by palm frond canopies and corrugated iron planks surround the beach on the landside. Bellevue, owned by George Suleiman Nakhleh, has been cited by Al Akhbar newspaper (Zbeeb, $2012 \mathrm{~b}$ ) as one of the numerous beaches that have violated many urban development regulations, including illegal reclamation projects to extend their land holdings.

The labour structure within the resort resembles that of other leisure spaces in Beirut: the management are likely related to the ownership; there are Lebanese or Syrian female staff who handle money and work in the kiosks selling food and non-alcoholic drinks; and there are

${ }^{6}$ To purchase land or apartments, Palestinians have to enter complex partnership arrangements with Lebanese friends or relatives. 
This is the accepted version of an article published by Sage in Environment and Planning D: Society and Space Vol. 34 (4), 583-600. Published version available from: https://doi.org/10.1177/0263775815623538

Accepted version downloaded from SOAS Research Online: http://eprints.soas.ac.uk/22575/ under licence CC-BYNC 4.0 International

migrant workers -here young East African women- who perform the menial tasks (cleaning, stoking shisha coal etc.).

Starting in early summer, the opening hours of Bellevue Beach extend from 10 am to around 6 $\mathrm{pm}$. At the time of this research, the entry fee on weekdays was 15,000 LL (or around \$10) per adult (and a bit less for children). The fee increases slightly on Saturdays and Sunday. ${ }^{7}$ Although $\$ 10$ may not seem like a great sum, in the context of $\$ 500$ average monthly salaries (including those of Hala and Sara's), it is a substantial outlay.

The resort stretches for 200 metres along the beach and includes several seating areas with sunloungers and tables and chairs primarily arrayed in orderly lines on the concrete spaces around the swimming pools. There are 2 swimming pools with waterslides for children, 2 swimming pools for adults and three shallower pools for toddlers. The resort also has two un-chlorinated rock pools near the beach. The sun loungers and beach umbrellas on the sandy beach are not as frequently used as the seats around the pools. The beach was first established in the 1970s, and the first swimming pool was constructed in 1982, the last completed in 1997. The beach became exclusive to women in 1994. The resort also includes a dance-floor in a thatched gazebo, and several snack kiosks.

Hala, Sara and Sirene usually set up for the day in the northernmost part of the resort under a corrugated iron roof near one of the pools and not too far from the gorgeous sandy beach. They claim seats by laying their towels on them; and after undressing in situ or in the changing rooms, they light their shishas. They then spend the rest of their time alternating between the sea, the swimming pool, or the shade. They prefer not to use sunscreen, and by the end of the day they are often bright red. As they have brought their own food and charcoal, they do not buy food from the kiosks or use the services of the charcoal lady, thus saving substantial amounts of money.

Hala, Sara and Sirene often gossip about the camp, their work, or the other people at the pool while bobbing in the warm sea. Sara also swims laps in the pool, while Hala and Sirene cling to the side. They wear bikinis that have string tops and boy-shorts. Throughout the day, Arabic and Western pop music pours from the loudspeakers. In the afternoon, a DJ spins Lebanese or other Arab dance music and many young women dance in the thatched gazebo in the centre of the resort. Hala, Sara, and Sirene sometimes dance, but more often prefer to people-watch and comment on the dancers. They use a combination of Arabic and Euro-pop dance moves, while ululating, clapping, or singing along. Sometimes Hala, Sara and Sirene converse with others. More often than not these conversations are triggered by the other beachgoers recognising the young women's Palestinian accents, and their encounters are almost always friendly.

At the end of the day, the beachgoers stream out of the resort in groups, some wearing fashionable and colourful headscarves, others with their hair unshod, and a handful clad in the black abaya associated with pious Shi'a women. Many catch the waiting minibuses home while others walk to the highway and still others set out in their cars. They are often exhausted, sunburnt, chatty and happy. They later post pictures of themselves looking rosy-cheeked on Facebook, receiving jokey or envious comments in SMS Arabic. They of course never take photographs of themselves in their swimsuits, but occasionally post an artful image of a burning

\footnotetext{
${ }^{7}$ See the website for the beach at http://www.bellevuebeach-lb.com/about $\% 20$ us, last accessed on 21 September 2014. Bellevue is not the cheapest of beaches, but it is far from being the most expensive. In contrast to Bellevue, access to the Riviera Hotel Beach in Beirut costs 48,000 LL or more than $\$ 30$.
} 
This is the accepted version of an article published by Sage in Environment and Planning D: Society and Space Vol. 34 (4), 583-600. Published version available from: https://doi.org/10.1177/0263775815623538

Accepted version downloaded from SOAS Research Online: http://eprints.soas.ac.uk/22575/ under licence CC-BYNC 4.0 International

brazier or a smoking shisha. These are often accompanied with comments about their love of smoking.

On other weekend evenings, Hala, Sara and Sirene, and sometimes other friends, including European NGO workers, go to shisha cafes in the nearby middle-class neighbourhoods of Chiyah or Burj Al-Barajna, or to the more expensive cafes on the Raouche, the seaside cliffs on the western end of Beirut. ${ }^{8}$ They do dress up for these occasions, carefully applying makeup and matching their headscarves to their handbags, shoes or their layered shirts. As a group they are playful and assertive and loud, and although groups of young men try to chat them up, they often remain wittily aloof and enjoy their time talking to one another, smoking shishas, having coffee, and sometimes mezzes. Again, their Palestinian accents are proudly on display and they have clear sense of themselves as daughters of Palestinian camp-cum-nation.

Sometimes, in early evenings, they go promenading on the Corniche or visit the eye-wateringly expensive Zaytuna Bay. ${ }^{9}$ The former is perhaps the last public space left in Beirut; the latter is a closely monitored private space to which the working classes can be admitted if they are sufficiently well-dressed and well-groomed. ${ }^{10}$ In Zaytuna Bay, the women wander about, take selfies amidst the landscaping and window-shop. On the Corniche, they can actually afford to consume coffee or seeds or yellow fava beans. Sometimes, Sara who knows how to ride a bicycle will hire a bicycle in Ain al-Mraiseh for an hour (at around \$10) and ride along the Corniche, all the way West to Hammam al-Askari and back. In those moments Hala and Sirene and their other companions sit on the benches overlooking the sea and chat, eat watermelon and pumpkin seeds, or people-watch. In Zaytuna Bay, their manners shift to conform to rules of propriety prevalent amidst the middle and upper classes, but they do not mask their Palestinianness. Promenading on the Corniche is much more casual and carefree; they often encounter people they know from the camp or Palestinian events, and have light-hearted banter with strangers.

Access to the Corniche is more democratic than to Zaytuna Bay. Although the police frequently harass Syrian food vendors on the Corniche, and keep an eye on rambunctious men, nevertheless the space is not unwelcoming to working class people from neighbourhoods outside of middle class Ra's Beirut. It also differs from Bellevue Beach, because although the beach is certainly not a luxurious sandbox for the rich, it nevertheless requires an entry fee, which can for many Beirutis constitute a substantial expenditure for a day of leisure activities.

\section{The Pleasures of the Beach}

In his magisterial history of European beachgoing, Alain Corbin (1994) describes the $18^{\text {th }}$ and $19^{\text {th }}$ century transformation of the seaside from a domain of fear, disrepute, or labour into a space of pleasure, promenading, and leisure (also see Rojek, 1993). The development of beaches and beach resort as places of bourgeois leisure in the Middle East has been traced to the early- to mid-twentieth century (Hazbun, 2010; Lagerquist, 2006), and Beirut seems to have preceded other eastern or southern Mediterranean cities in the development of its beaches.

\footnotetext{
${ }^{8}$ On the cafes of Chiyah, Burj al-Barajna, and other southern suburban neighbourhoods, see Deeb and Harb, 2013.

${ }^{9}$ Zaytuna bay is a yacht marina reclaimed from the sea, with shops, restaurants and cafes many of which are branches of European and US chains. The area was developed by a private joint venture between Solidere and Stow Development Company (whose primary investor is Mohammad al-Safadi, Lebanese Finance Minister between 2011 and 2014). On Solidere, see Leenders, 2012, pages 58-67; Sawalha, 2010.

10 Two ostensibly "public" parks remain in Beirut: Horsh Beirut in the southern part of the city, and Sanaye' Gardens near Hamra. However, the former is perpetually closed (recently opening for only one evening), and the latter is rigorously guarded by private security guards.
} 
This is the accepted version of an article published by Sage in Environment and Planning D: Society and Space Vol. 34 (4), 583-600. Published version available from: https://doi.org/10.1177/0263775815623538

Accepted version downloaded from SOAS Research Online: http://eprints.soas.ac.uk/22575/ under licence CC-BYNC 4.0 International

By the end of the $19^{\text {th }}$ century, a French visitor to Beirut counted "five public baths, ten public fountains, [...] fifty-five cafes, ten public beaches, two public gardens" alongside hotels, casinos, libraries, printing presses and various other businesses (Hanssen, 2005, pages 195-196). At that time, the beaches were used for popular religious festivals celebrating various sects' saints (Hanssen, 2005, page 198). Young men used "the cliffs of Medawar to the east and ... the edge of Minet al-Hosn to the West" for bathing in the sea (Kassir, 2010, page 219). By the Mandatory period in the mid-1930s, beach resorts had begun appearing throughout Beirut and women had also begun sea-swimming.

The pleasures of the water were from the very beginning classed. "Ocean swimming and cliffdiving competitions at Rawsheh [sic] were the province of the Beirut working class, and more specifically the Sunni youth of the coastal neighbourhoods, whereas water-skiing, yachting, and competitive swimming in twenty-five-meter pools were reserved for the upper classes" (Kassir, 2010, page 395). Even the beach clubs and resorts that began emerging up and down the coast, and especially in Beirut, had differing class complexions; the upper classes frequented the beaches of Saint-Georges and Saint-Simon, while "intellectuals and upper-middle-class professionals" used Sporting and Long Beach Club (Kassir 2010, page 396). Even today, different beaches have different constituencies. While Sporting and Hammam al-Askari primarily cater to middle-classes and military families respectively, Jisr beach near Damour is affectionately called the "Communist Beach" while one of the women-only beaches between Beirut and Saida is labelled the "Hizbullah Beach," the former because it is owned by the Communist Party of Lebanon, the latter because it is frequented by women who are thought to be followers of the Party.

It is notable that almost all the beach resorts in which women and families feel most comfortable are private. The handful of beaches that remain free from fees are frequented by families only during festivals, for example at iftar during Ramadan. Ramlat al-Bayda beach, the last freely accessible beach in Beirut, is often patronised by boisterous working class shebab (young men). These beaches exclude young women -especially if unchaperoned by family members- by virtue of their prevalent atmosphere of masculine banter and practices of harassment that they sometimes engender.

In addition to gender-specific modes of usage of and exclusion from beaches, the ongoing process of expropriation and enclosure strips the broader Lebanese public of their public beaches. The Dictaphone Group, inter alia, has recorded this process of expropriation for almost all the beaches along the Beirut coastline in their This Sea Is Mine (2013). ${ }^{11}$ Since 2013, Daliyeh beach, a rocky diving and fishing area, which had long been used "for family picnics, lovers" romantic hideouts, as a hub for swimmers and divers, a port for fishermen, and by hundreds of Lebanon's Kurdish population who headed there to celebrate Nowruz at the dawn of spring" was enclosed and is slated for "development" by the Hariri family's business concerns (al-Saadi, 2014). The same fate now awaits Ramlat al-Bayda beach (Wehbe, 2014).

I mention this privatisation of public beaches in order to draw attention to two relevant points. First, rules of proper and decent behaviour for women demand a certain degree of "privacy" in public which is not easily provided by unsegregated spaces, particularly beaches, where men's exuberant and sometimes aggressive behaviour would threaten the women's ability to partake of a safe conviviality. Second and far more important, the enclosure (read: theft) of public spaces in

\footnotetext{
11 The Dictaphone group consists of a number of women artists and urban planners whose public performances are aimed at educating the public about the accelerated privatisation of public spaces through carefully researched and joyfully interactive performances.
} 
This is the accepted version of an article published by Sage in Environment and Planning D: Society and Space Vol. 34 (4), 583-600. Published version available from: https://doi.org/10.1177/0263775815623538

Accepted version downloaded from SOAS Research Online: http://eprints.soas.ac.uk/22575/ under licence CC-BYNC 4.0 International

Lebanon has characterised its economy since the very inception of state -making Lebanon the prototype of neoliberal state par excellence. Here, the convergence of state power and private capital, often physically embodied in the same persons and families strips the public of any remaining right to spatial commons, and therefore is directly in tension with convivial practices which such spaces can produce.

\section{Promenading on the Corniche}

While freely accessible beaches are gradually vanishing, the Corniche remains the last truly public space in Beirut. Early mornings see people exercising there. On warm evenings, the promenade is used by a broad range of people, from middle class joggers and dog-walkers to working class families who bring their picnics, shishas, and even charcoal grills with them, to young men who cluster in groups, to mixed groups of young people, to romantic couples. Not to be forgotten are fishermen and -women with both sophisticated and basic fishing equipment. The pedestrians have to occasionally accommodate cyclists who veer among them. All are served by food vendors with their carts, and can also buy coffee from cafes and kiosks and shops on the other side of the dual carriageway that separates the promenade from the neighbourhood high-rise buildings most of which are bereft of inhabitants.

In Europe, promenading, like beachgoing, emerged in the $18^{\text {tt }}$ and $19^{\text {th }}$ centuries as a form of bourgeois sociability (Scobey 1992). In that context, promenading "dramatized the legitimacy of social distinction, not social equality" (Scobey, 1992, page 206) and embodied a kind of bourgeois "politeness". However, in Beirut, promenading has been anything but "polite," though of course its emergence has also been tied to the rise of the local bourgeoisie.

The Corniche was one of the many public spaces that was utilised for promenading in the last quarter of the nineteenth century (Kassir, 2010, page 216); Sahat al-Burj, in the central business district of Beirut, was another. In his account of fin de siècle Beirut, Jens Hanssen (2005, page 197) tells the story of how such public spaces "became spaces where not only Ottoman flâneurs with their red fezzes and black frocks were ridiculed, but where stinging social criticism avoided punishment." The Corniche has continued to be a public space used by families and simultaneously a marginal space of transgression, as Sofian Merabet's recent work on Queer Beirut (2014) shows. Merabet dedicates perceptive passages to "certain stretches of the Corniche as zones of encounter" between men seeking homosexual interactions (2014, page 167).

But promenading on the Corniche is primarily a non-transgressive form of leisure in which people from across the political, sectarian and class spectrum participate (Delpal, 2015), and which is a major public feature of many Arab cities, from Cairo and Istanbul to Abu Dhabi and Muscat, among many others. This form of promenading is not necessarily about the dissident gaze of the flâneurs about whom Walter Benjamin so strikingly wrote (Buck-Morss, 1989; 2006; Hanssen, 2006). It is a brief moment of encounter under evening skies and by bodies of water. As Deeb and Harb's interlocutors recounted, the Corniche provided the opportunity "to go to the sea to walk, breathe fresh air, enjoy the view of an open horizon, relax and forget their worries, play and laugh. They contrasted the sea with Dahiya's density, traffic, and pollution, and saw it as an escape from the stress of urban life" (2103, page $255 \mathrm{fn} 4)$. The promenade is also about seeing and being seen and opening up a space of play, flirtation, and interaction.

The distinguishing feature of promenading on the Corniche is that it is a form of leisure that requires no exchange of money, and as such the young women from the camp can engage in it 
This is the accepted version of an article published by Sage in Environment and Planning D: Society and Space Vol. 34 (4), 583-600. Published version available from: https://doi.org/10.1177/0263775815623538

Accepted version downloaded from SOAS Research Online: http://eprints.soas.ac.uk/22575/ under licence CC-BYNC 4.0 International

without committing to any expenditure. But the absence of monetary exchange and consumerism does not mean that these practices are about resistance.

\section{Not (necessarily) About Resistance}

Some perceptive recent works have described fun or pleasure as ways of resisting state restrictions on public behaviours, or as social safety valves, or as conscious means of politicking (Bayat, 2010; Khosravi, 2008; Van Doorn, 2013; Verkaaik, 2004). In a discussion of play and leisure in Ramallah, Lisa Taraki (2008, page 17) outlines the transformation of Palestinian understanding of resilience from one "based on an ascetic denial of frivolity, joy, or entertainment" to one that "renders the very pursuit of happiness a manifestation of resilience and of resistance at the same time." Taraki (2008, page 17) bitingly explains this as the Palestinian bourgeoisie's "need to ennoble its pursuit of happiness by casting it as a form of resistance." Lara Deeb and Mona Harb's Leisurely Islam, by contrast argues that the majority of their interlocutors are happy not resisting the order of things in their neighbourhoods. They illuminate how leisure activities -café-going and convivial public gatherings in particular-are reconciled with piety and commitment via adherence to a series of rules of propriety. Concurrently, these rules themselves shift imperceptibly in response to convivial practices.

Young Palestinian women's pleasure in promenading or beachgoing is not about moral incorporation of leisure, although of course by attending a women-only beach or by observing hijab and single-sex promenading they are in fact being proper. More importantly, when they speak of having pleasure at the beach or the Corniche, they don't articulate this sense of joy as a moment of resistance. The burden of resisting is heavy and familiar for Palestinians, precisely because so much of their lives are circumscribed by policies of separation, segregation, occupation, ghettoization and violence; and precisely because nationalism as a structuring frame has been so prevalent in their lives, their social organisation, and their political mobilisation. The women understand their pleasures as a sphere distinct and discrete from the domain of resistance, even as they declare their Palestinianness publicly and loudly in ways unthinkable a few years ago. ${ }^{12}$

In some ways, if there is a resistance, it is to the notion that their quotidian activities can be interpreted as an inexorable drive towards revolutionary resistance. They exult a kind of ordinariness Toby Kelly has wryly called "the attractions of accountancy." Kelly (2008, page 362) argues that all ordinary practices can be read as resistance and as its opposite, and he asks, "was walking around a checkpoint, an act that could certainly be very dangerous, a form of resistance or was it simply acquiescence to the status quo dressed up as a form of nationalist activity?" The practices I describe here do not even have the veneer of danger that would allow us to locate them under the sign of resistance. Though moral or reputational danger is a possibility.

\footnotetext{
12 Until very recently, that given broader hostility to Palestinian presence in Beirut, many Palestinians felt that their sphere of movement was confined to the camps and the subject of extraordinarily harsh economic and political control measures. But in the last five years, some of these restrictions have relatively attenuated. Some of this attenuation is because as the years of civil war have receded, the boundaries of some of the camps have become far more blurred and the city and camp have become much more interwoven (at least as regards Shatila camp; see for example Martin, 2015). Burj al-Barajna is still more distinct from its surroundings as can even be observed from aerial photographs that show a clearly delineated space far denser than its surrounding neighbourhoods. Ethnographic experience within Burj al-Barajna similarly shows that its boundaries and relations to the neighbourhood are distinct from Shatila's.
} 
This is the accepted version of an article published by Sage in Environment and Planning D: Society and Space Vol. 34 (4), 583-600. Published version available from: https://doi.org/10.1177/0263775815623538

Accepted version downloaded from SOAS Research Online: http://eprints.soas.ac.uk/22575/ under licence CC-BYNC 4.0 International

In subverting norms of propriety in public, as the young women certainly do by smoking shishas in cafes, chatting loudly and flamboyantly on the Corniche, and dressing in tiny bikinis on the women-only beach, they are transgressing against forms of gender monitoring. This argument has been challenged by Lila Abu-Lughod, who does not view young women's novel forms of comportment as a resistance against the strictures of older matriarchs, or against the gendered order of domination enforced by their male relatives. Rather, Abu-Lughod (1990, page 50) argues that by being "more involved in the kind of sexualized femininity associated with the world of consumerism-even if it is only the comparatively small-time world of five-dollar nightgowns and 15-cent nail polish-[the young women] are becoming increasingly enmeshed in new sets of power relations of which they are scarcely aware."

If the young women are not resisting, one interpretation of their activities can be that they are reinforcing forms of consumerism that are hegemonic in Beirut as elsewhere. Abu-Lughod's parenthetical example about nail polish matters here. The exchange of money, in paying the beach entry fees and in purchasing the accoutrements of beachgoing or promenading -bikinis, fashion hijab, tighter clothes that allow the young women to blend in with their Beiruti counterparts- all point to their enmeshment in the political economy of leisure and consumerism. But, given that there is no space outside this matrix, it is simply impossible to step outside this warren of exchange and consumption.

In fact, this space of consumption from which there is no escape is the nightmarish view Walter Benjamin developed towards the end of his life, in which people on the street were essentially "a massified clientele" of totalitarian states (quoted in Buck-Morss, 1989, page 307). Notably, Benjamin's 1940s view of the collective on the street, congruent with its context of National Socialism, drastically differs from his own view of the public as collective humanity claiming the streets a decade earlier, where street presence was about conviviality (Buck-Morss, 1989, pages 304-305).

These contrasting views encapsulate the extremities of arguments around entertainment, leisure, and the culture industry whose most vociferous proponent was Theodor Adorno. Adorno's writings on the culture industry are well known, but here I discuss a shorter essay, "Free Time," in which he is of two minds about leisure. On the one hand, Adorno argues that free time is a "continuation of the forms of profit-orientated social life," but on the other hand, he also argues that "even fooling about need not be inane and can be enjoyed blissfully as a dispensation from the mechanisms of self-control" (1991, pages 171-172). For him, as for Benjamin before him, and Herbert Marcuse after him, what distinguishes the boredom of being co-opted into the regime of consumption from the playful release of the eros is autonomy, a life "determined by free people for themselves" (Adorno, 1991, page 171). It is precisely the totalising force of capitalist production and consumption that prevents the possibility of such freedom. Marcuse similarly saw in the exchange of goods a circumscription of people's fundamental autonomy: "the goods and services that the individuals buy control their needs and petrify their faculties. In exchange for the commodities that enrich their life, the individuals sell not only their labor but also their free time. The better living is offset by the all-pervasive control over living." ((1956)1987, page 100).

In the case of my Palestinian interlocutors, their lives are defined by both the discipline of work and the disciplinary apparatuses of humanitarian and development aid. And yet, I argue that, their free time is indeed an escape from these grids of control. Perhaps it is important to make the banal point that the general concepts of embourgeoisement and consumerism manifest in specific ways in different contexts and temporal eras. The young women from the camp may be better off than their cohorts in the camp, but relative to the Beirutis they encounter -even in 
This is the accepted version of an article published by Sage in Environment and Planning D: Society and Space Vol. 34 (4), 583-600. Published version available from: https://doi.org/10.1177/0263775815623538

Accepted version downloaded from SOAS Research Online: http://eprints.soas.ac.uk/22575/ under licence CC-BYNC 4.0 International

neighbourhoods near the camp- they are still less affluent. Their patterns of consumption are still incomparable with those who earn more than they do, and they window-shop and fantasise far more than they shop or spend.

Further, and perhaps more significantly, Palestinian access to public Beiruti spaces has historically been drastically and violently curtailed. When I first began visiting Beirut fifteen years ago, the parents of these young women had a much narrower space of circulation, and their mothers never even left the camp or its immediate vicinity. The invisible lines demarcating the camp and various Beirut neighbourhoods were for a while erased, but with the intensification of conflicts (which variously map to different and overlapping sectarian and political allegiances), neighbourhoods have become once again impermeable to each other. Paradoxically, just as neighbourhoods are securitised (Fawaz et al, 2012) Palestinians are increasingly appearing outside the camps. Several political transformations underwrite this expansion of spaces available to Palestinians: first and foremost, a loosening of limits on Palestinian labour in Lebanon means that they now find work outside the camp, as is the case with the Palestinian women who star in this article. But also because the camps are not currently directly enmeshed in the conflicts surrounding them (as they did as recently as 2006), and further still because the current pharmakos of Lebanese politics seem to be Syrian refugees (including Palestinians from Syria who are read even by Palestinians in Lebanon- as "Syrians"), Beirut's Palestinians have seen a relative shift in the glare of attention directed at them. It is important to specify that although Beirut itself has seen inter- and intra-neighbourhood sectarian skirmishes, the camps have remained aloof from the affray. This is partially because Palestinians who may have joined the different sides in the confrontations have done so outside the camps, but also because the complex relations of discipline and authority drawing from Palestinian familial networks and political matrices arbitrate conflicts and maintain a relative peace -however fragile and provisional- within the camps themselves.

This relative spatial opening for Palestinians-however narrow, circumstantial and recentcrucially shifts the meaning of Palestinian women's practices of pleasure. Promenading and beachgoing not only become activities from which they previously had been financially and politically excluded. So here, pleasure-seeking practices exceed their meaning as a modest engulfment in capitalist exchange: they are also about the histories of exclusion, of denigration and marginalization of Palestinians in Lebanon. And most importantly, partaking of public and semi-public spaces are acts of conviviality; of placing oneself within a collective and feeling however fleetingly- a life lived in common.

\section{The Austerity of Political Commitment}

What is particular to Palestinian mobilisational politics here is the extent to which such modest politics of pleasure trouble the question of political commitment, which is frequently defined as necessarily austere. Such "ethos of self-restraint" (Jean-Klein, 2001, page 96) has been a characteristic of Palestinian political mobilisation at least since the First Intifada (1987-1991). This ethos "combines subaltern, oppositional, and emancipatory impulses with hegemonic and, if not oppressive, in any event newly constraining, nation-building impulses" (Jean-Klein, 2001, page 91), and most often is characterised by a rejection of joyful celebrations (even weddings) as a sign of respect not only for those martyred in struggle, but more abstractly as a symbol of unconditional commitment to the cause itself (e.g., Jad, 2009; Johnson et al, 2009).

This insistence on "conformity of existence as the condition of militantism" (Foucault, 2011, page 186) is of course not limited to or even characteristic of Palestinian nationalist movement, 
This is the accepted version of an article published by Sage in Environment and Planning D: Society and Space Vol. 34 (4), 583-600. Published version available from: https://doi.org/10.1177/0263775815623538

Accepted version downloaded from SOAS Research Online: http://eprints.soas.ac.uk/22575/ under licence CC-BYNC 4.0 International

or of anticolonial nationalist movements in general. Communist Parties of all places have at various times adopted anhedonist or austere "styles of life." For example, Foucault (2011, page 186) writes critically about the French Communist Party's" implementation of accepted values, customary behaviour, and traditional schemas of conduct" that disciplined the members in austere ways.

In such settings, adopting a style of life that does not disturb dominant normative precepts is explained in a variety of ways: such austere behaviour remains respectful to spilled blood and suffering of those who struggle. Or such self-restraint does not alienate a broader public. Or such fleshy pleasures are a sign of bourgeois decadence, or enervation of the will to revolt. Or such pleasure needs to be deferred until the utopia.

There is another context in which the rejection of joy and happiness serves a political end. Where "happiness" becomes shorn of its myriad meanings and subversive capacities and is reduced either to a utilitarian calculus, assimilated to forms of population management, or becomes an index of acquiescence to power, then being a killjoy, resisting pleasure, becomes a politically necessary act. Laura Mulvey (1975) famously argued for "the destruction of pleasure as a radical weapon" in order to counter a male gaze upon bodies of women on the screen. Similarly, reflecting on African-American music, Ishmael Reed (1998, page 169) considers "black pleasure an oxymoron." A significant body of feminist and queer scholarship points to the insidiousness of the demand for happiness (e.g. Ahmed, 2010; Halberstam, 2011). This is eloquently articulated in an exchange between Lisa Duggan and the late Jose Munõz (2009, page 276) in which Duggan persuasively argues that

When I think about hope, I set it alongside happiness and optimism, which I immediately associate with race and class privilege, with imperial hubris, with gender and sexual conventions, with maldistributed forms of security both national and personal. They can operate as the affective reward for conformity, the privatized emotional bonus for the right kind of investments in the family, private property and the state.

And yet. Mobilising against happiness and pleasure are geographically and temporally specific. In the same conversation, Duggan and Muñoz (2009, page 280) recognise that there are even pleasures to be had in the "bitterness, cynicism and pain" assimilated to a queer sensibility.

In the Beiruti context I have thus far described, two factors mitigate exhortations about the right to anger and the rejection of pleasures: first, relative class locations and second, the collective natures of pleasures. My argument about these pleasures is modest. These forms of public pleasure appropriate public spaces in the service of conviviality -a 'life in common' (Lloyd, 2011; van Doorn, 2013), and this act of collective and public pleasure acts as a caesura in the rigidity and atomisation of workplace discipline and domestic pressure.

\section{The Generosity of Conviviality}

In a heroically utopian landscape defined by the dramatic summits and precipices of struggle and resistance, conviviality might seem all too humble a hillock to feature. But everyday life in urban spaces is a complex agglomeration of encounters and conflicts, work and violence, leisure and loneliness. We live in times where the demands of work and discipline transform us into monads. Recent politics in the region more broadly and Beirut specifically have transformed fictive lines of sectarian and neighbourhood and national demarcation into checkpoints and barbed-wire fences. In a moment of segregation and atomisation, conviviality is more than moving through a space also occupied by others. As Jane Bennett has written, it is "cultivating a 
This is the accepted version of an article published by Sage in Environment and Planning D: Society and Space Vol. 34 (4), 583-600. Published version available from: https://doi.org/10.1177/0263775815623538

Accepted version downloaded from SOAS Research Online: http://eprints.soas.ac.uk/22575/ under licence CC-BYNC 4.0 International

stance of presumptive generosity" which requires "rendering oneself more open to the surprise of other selves and bodies and more willing and able to enter into productive assemblages with them" (Bennett, 2001, page 131).

In another context, Paul Gilroy (2004, page xi) has similarly defended conviviality as "the process of cohabitation and interaction that have made multiculture an ordinary feature of social life in Britain's urban areas and in postcolonial cities elsewhere." Gilroy recognises that neither racism nor inequality have disappeared, nor is this cohabitation always harmonious, but that it requires a breaking down of the proverbial and concrete walls (2004, pages 78-79). For Gilroy, as for my Palestinian interlocutors, the urban context and its peripheries and extensions at the seaside matter as the site of such interactions and encounters.

In her reading of Benjamin's Arcades, Susan Buck-Morss has argued that the oppressed and oppressor have different perception of public spaces with the oppressed finding public spaces to be domains of "state surveillance, public censure and political constraint" (2006, page 48). But in Beirut, the context is different: small houses in the cramped and monitored spaces of the camp make a mockery of the notion of privacy, and the demand -both of the Lebanese state and of the gendered strictures of propriety- to remain within the bounds of the camp make the "inside" the space of "state surveillance, public censure and political constraint" and the outside a space in which surveillance and constraint is attenuated by the encounter with others. In a way, the situation of Palestinians in the camps in Lebanon is much closer to Lefebvre's analysis (2014, page 5) of the reversal of inside/outside in proletarian housing where, "reduced to a minimum, barely 'vital,' it depends on various 'facilities,' on the 'environment,' that is, on social space, even if this is not well-maintained. There is no connection with enjoyment other than in and through external space."

The social conflicts that necessitate a precious -if tenuous- conviviality in European cities of course differ from the myriad forms of strife -sectarian foremost among them- that have made Beirut a tense city space where the peril of violent encounters pulsates under the surface of everyday interactions. But portrayals of Beirut as a tinderbox -or as a site of constant confrontation- elide these provisional and sometimes-ephemeral practices of urban conviviality that materialise in public spaces and can dissipate or reconstitute in different places and times. It is also important to note that residents of Beirut do not experience these potentialities of danger and confrontation in the same way and within the same temporal constraints. While class privileges can insulate some from these forms of conflict, surprisingly, being Palestinians, and being Palestinian women in Beirut, can provide a measure of distance from the Lebanese forms of sectarian conflict. There are moments that although clashes are occurring in one part of the city, the primary concern of people in other parts of the city are the daily drudgery of work, and the momentary escapes from its travails through practices of conviviality.

Young Palestinian women's presence in public is drenched in different forms of conviviality: they strike up conversations with those around them as Palestinians; they people-watch; they inhabit public and pseudo-public spaces with their shishas, their bicycles, their bikinis, their voices, their laughter. They dance and play and walk. They claim their right to the beach however privatised, to the promenade however circumscribed, to the city streets of Beirut however much disallowed. They partake of a set of common and collective pleasures.

Perhaps more important is the extent to which such conviviality is an alternative to the dullness of their work, from nine to five, in offices. Where such labour guarantees their ability to pay the entry fees for the beach and the accoutrement of pleasure, it also is deadening and alienating in its demands and discipline. As Kathi Weeks has written so perceptively, "[the] worldliness of, for 
This is the accepted version of an article published by Sage in Environment and Planning D: Society and Space Vol. 34 (4), 583-600. Published version available from: https://doi.org/10.1177/0263775815623538

Accepted version downloaded from SOAS Research Online: http://eprints.soas.ac.uk/22575/ under licence CC-BYNC 4.0 International

example, unruly bodies, seductive pleasures, and spontaneous enjoyment poses a constant challenge to the mandate for such focused attention to and diligent effort in properly productive pursuits" (Weeks, 2011, page 48).

In fact if we think of utopia not just as heroic futures but also of "ordinary habit" (Cvetkovich, 2012) and of "play" (Bakhtin 1984, page 235), then this conviviality has something utopian about it. In his extraordinary story of Irish orality, David Lloyd (2011, page 109) has argued that the Irish public house is "a potentially alternative space for homosocial conviviality that operated outside the norms and rhythms of alienated labour or the hierarchies of the workspace that impinge on [the pub-goers'] daily life." I think promenading and beachgoing function a little like the Irish pub. In their producing of homosocial conviviality and heterosocial play they also produce a utopia that is rooted in the present and is a "realization of abundance out of scarcity and of fulfilled pleasure out of the partial, threatened, yet irreducible pleasures of the present" (Lloyd, 2011, page 17).

Further, the pleasure of laughter and speaking loudly, of the body's will to inhabit space fully, of the openness of the horizon, and the sultriness of sea air, laced though it may be with diesel fuel and smog are all ways of becoming visible. The body has always been the object of discipline, and a woman's body doubly so. Such pleasures of the flesh, and especially loitering and loud laughter in public, are considered lewd, untoward, improper (Phadke, 2011). Politics of respectability often demand demureness and invisibility. Being in public is a refusal of enforced invisibility.

Social structures, political strictures, privatisation of public spaces, the discipline of work, and the contraction of conviviality, all demand these women to shrink back, to become invisible. They are supposed be invisible as women, as Palestinians, or as Beiruti residents partaking of air and sea and urban life. Pleasure becomes congealed corporeally and is carried away for another day, as a resource against the disciplines.

\section{Final Argument}

if what people today imagine to be pleasure is nothing but a commodity fix, how to deal with that addiction? Who is to break the news to them that their conscious experience of leisure products -their conscious 'pleasure' in consumption- is in reality nothing but false consciousness? Indeed, even further, who has the authority -and in the name of what? - to make such an assessment?

Frederic Jameson, "Pleasure: a Political Issue"

I have argued for the specificity of Palestinian refugee women's pleasure. The demand for propriety enmeshes young Palestinian women in a set of overlapping disciplinary grids that base subjecthood on the normative injunctions to self-denial and docility. This docile subject is then assigned to an ever more restricted space of the camp. When the young woman breaks out, when she speaks in a loud Palestinian accent in a public space of leisure, when she declares herself at a beach or on the Corniche, she is making visible not just a Palestinian in a Lebanese space but a Palestinian woman in a Lebanese public space. This may or may not be an act of resistance; but it is a recuperation of a sense of wonder at the world, and a demand to physically inhabit it. It is a claim to the city, and a demand to replace the alienating and monadic discipline of work with the 
This is the accepted version of an article published by Sage in Environment and Planning D: Society and Space Vol. 34 (4), 583-600. Published version available from: https://doi.org/10.1177/0263775815623538

Accepted version downloaded from SOAS Research Online: http://eprints.soas.ac.uk/22575/ under licence CC-BYNC 4.0 International

ephemeral conviviality of being in public, and the sense, however transitory and superficial of a life in common.

The context matters. Where the entire edifice of consumerism, hyper-capitalism, and therapeutic culture in the global North demands a kind of benumbed, atomised and individualistic happiness, being a killjoy is a necessary form of resistance. But the lives of Palestinian women in the camps do not belong to these spaces of pure consumerism, yet. Their lives are defined by histories of marginalisation within the cities they and their families have inhabited for decades, and it is their incorporation into the regime of work that demands of them discipline. Thus pleasurable pursuits open up spaces for ephemeral, transitory moments of happiness in the temporal crush of suffering and trauma. But even more importantly, their acts of pleasure locate them outside the atomisation of work discipline and the separation of the refugee camp, in a collective space in which an ever-squeezed public partakes of the complimentary pleasures of a beach or a seaside or a sunset.

There is an argument that suffering and trauma act as engines of mobilisation. As Walter Benjamin (1968, page 260) has written, the working class needs to nourish "its hatred and spirit of sacrifice... by the image of enslaved ancestors rather than that of liberated grandchildren." 13 But, as I have argued elsewhere (2007), suffering, that memory of "enslaved ancestors," can also be co-opted into institutional arrangements which in fact demobilise, or can become a spectacle for far observers who are moved to pity, but not action. There is nothing fundamentally liberating about suffering itself. Suffering is in fact evocative of a particularly Christian notion of redemption, where today's pain and the deferral of gratification are seen to lead to an inevitable future salvation, so far in the future as to be hazily abstract. This always unreachable telos demands we ignore the fragility and provisionality of life right now. It ignores the demand for fun, for forestalling the inevitability of death, or violence or war or marriage, through grasping a momentary caesura.

I recognise how such momentary pleasure is a ripple on the surface not just of the lives of these women, but of the political life of the city. I recognise that such pleasures can coexist with political cynicism (Allen, 2013) or forms of depoliticisation. I can see how such pleasures are consumerist, although I do not know how to find a space outside of consumerism today if the consumption even of "15-cent nail polish" traps us in the circuits of exchange. My concern is that I, we, write in scholarly journals and books, adjudicating the lives of others, measuring them against impossibly heroic indices of struggle, exhorting them towards grand utopias, demanding an austerity in commitment we ourselves do not observe. Life is many things: capitulation or struggle, anger or fear or laughter, silence and work and yes capitalist leisure. But it is also the joyous sense of a transitory presence in ever-shrinking public spaces of cities that are torn apart not just by war and violence but by the dull discipline of work. Such pleasure, today, can contrast with pasts of suffering and serve as a memory of future utopias.

\section{Bibliography}

Abu-Lughod L, 1990, "The Romance of Resistance: Tracing Transformations of Power through Bedouin Women" American Ethnologist 17 41-55

\footnotetext{
${ }^{13}$ Footnote 13: I am grateful to Rahul Rao for reminding me of this particular Benjamin thesis.
} 
This is the accepted version of an article published by Sage in Environment and Planning D: Society and Space Vol. 34 (4), 583-600. Published version available from: https://doi.org/10.1177/0263775815623538

Accepted version downloaded from SOAS Research Online: http://eprints.soas.ac.uk/22575/ under licence CC-BYNC 4.0 International

Adorno TW, 1991, "Free Time", in Critical Models: Interventions and Catchwords, trans Pickford HW (Columbia University Press, New York, NY) pp 167-176

Ahmed S, 2010 The Promise of Happiness (Duke University Press, Durham, NC)

Allen L, 2013 The Rise and Fall of Human Rights: Cynicism and Politics in Occupied Palestine (Stanford University Press, Stanford, CA)

Bakhtin M, 1984 Rabelais and His World, Trans Iswolsky H (Indian University Press, Bloomington, IN)

Bayat A, 2010 Life as Politics: How Ordinary People Change the Middle East (Stanford University Press, Stanford, CA)

Benjamin W, 1968 Illuminations Ed Arendt H trans Zohn H (Harcourt Brace Jovanovich Inc., New York, NY)

Bennett J, 2001 The Enchantment of Modern Life: Attachments, Crossings, and Ethics (Princeton University Press, Princeton, NJ)

Berlant L, 2011a, “A Properly Political Concept of Love: Three Approaches in Ten Pages” Cultural Antbropology 26 683-691

---. 2011b Cruel Optimism (Duke University Press, Durham, NC)

Binkley S, 2011, "Happiness, Positive Psychology and the Program of Neoliberal Governmentality" Subjectivity 4 371-394

Bok D, 2010 The Politics of Happiness: What Government Can Learn from the New Research on Well-Being (Princeton University Press, Princeton, NJ)

Buck-Morss S, 1989 The Dialectics of Seeing: Walter Benjamin and the Arcades Project (MIT Press, Cambridge, MA)

---. 2006, "The Flâneur, the Sandwichman and the Whore: The Politics of Loitering" in Walter Benjamin and the Arcades Project Ed Hanssen B (Continuum, London) pp 33-65

Corbin A, 1994 The Lure of the Sea: The Discovery of the Seaside in the Western World, 1750-1840 (University of California Press, Berkeley, CA)

Dean T, 2012, “The Biopolitics of Pleasure.” South Atlantic Quarterly 111 477-496.

Deeb L, Harb M, 2013 Leisurely Islam: Negotiating Geography and Morality in Sbi'ite South Beirut (Princeton University Press, Princeton, NJ)

Delpal C, 2015 "La Corniche de Beyrouth: Nouvel Espace Public" Les Annales de la Recherche Urbaine 91 74-82

Dictaphone Group, 2013 This Sea Is Mine, http://www.dictaphonegroup.com/wp/wpcontent/uploads/2013/11/SIM-booklet-compressed.pdf

Duggan L, Muñoz JE, 2009, "Hope and hopelessness: A dialogue” Women \& Performance: a journal of feminist theory 19 275-283

Fawaz M, Harb M, and Gharbieh A, 2012, "Living Beirut's Security Zones: An Investigation of the Modalities and Practice of Urban Security" City and Society 24 173-195

Foucault M, 2011 The Courage of Truth: The Government of Self and Others II; Lectures at the Collège de France 1983-1984 Ed Gros F, trans Burchell G (Palgrave Macmillan, London) 
This is the accepted version of an article published by Sage in Environment and Planning D: Society and Space Vol. 34 (4), 583-600. Published version available from: https://doi.org/10.1177/0263775815623538

Accepted version downloaded from SOAS Research Online: http://eprints.soas.ac.uk/22575/ under licence CC-BYNC 4.0 International

Freud, S, (1922) 1955 Beyond the Pleasure Principle In the Standard Edition of the Complete Psychological Works of Sigmund Vol XVIII Ed Strachey J (Hogarth Press, London)

Gilroy P, 2004 After Empire: Melancholia or Convivial Culture? (Routledge, London)

Halberstam J, 2011 The Queer Art of Failure (Duke University Press, Durham, NC)

Hanssen B ed. 2006 Walter Benjamin and the Arcades Project (Continuum, London)

Hanssen J, 2005 Fin de Siècle Beirut: The Making of an Ottoman Provincial Capital (Clarendon Press, Oxford)

Hazbun W, 2008 Beaches, Ruins, Resorts: The Politics of Tourism in the Arab World (Minnesota University Press, Minneapolis, MN)

---, 2010 "Modernity on the Beach: A Postcolonial View from Southern Shores" Tourist Studies 9 203-222

Jad I, 2009, "The Politics of Group Weddings in Palestine: Political and Gender Tensions." Journal of Middle East Women's Studies 5 36-53

Jameson F, 1983, "Pleasure: A Political Issue" in Formations of Pleasure Ed Jameson F (Routledge \& Kegan Paul Plc, London) pp 1-14

Jean-Klein I, 2001, "Nationalism and Resistance: The Two Faces of Everyday Activism in Palestine during the Intifada" Cultural Anthropology 6 83-126

Johnson P, Abu Nahleh L, and Moors A, 2009, "Weddings and War: Marriage Arrangements and Celebrations in Two Palestinian Intifadas" Journal of Middle East Women's Studies 511-35

Junka L, 2006 “The Politics of Gaza Beach” Third Text 20 417-428

Kassir S, 2010 Beirut Trans Debevoise MB (University of California Press, Berkeley, CA)

Kelly T, 2008, "The attractions of accountancy: Living an ordinary life during the second Palestinian Intifada" Ethnography 9 351-376

Khalili L, 2007 Heroes and Martyrs of Palestine: The Politics of National Commemoration (Cambridge University Press, Cambridge)

Khosravi S, 2008 Young and Defiant in Tehran (University of Pennsylvania Press, Philadelphia, PA)

Lacan J, 1981 The Four Fundamental Concepts of Psychoanalysis Trans Sheridan A (W.W. Norton, New York, NY)

Lagerquist P, 2006, "Vacation from History: Ethnic Cleansing as the Club Med Experience." Journal of Palestine Studies 36 43-53

Leenders R, 2012 Spoils of Truce: Corruption and State-Building in Postwar Lebanon (Cornell University Press, Ithaca, NY)

Lefebvre H, 2014 Toward an Architecture of Enjoyment, ed Stanz L trans Bononno R (University of Minnesota Press, Minneapolis, MN)

Lloyd D, 2011 Irish Culture and Colonial Modernity 1800-2000 (Cambridge University Press, Cambridge)

Marcuse H, (1956) 1987 Eros and Civilization: A Philosophical Inquiry into Freud (Routledge, London) Martin D, 2015 “From spaces of exception to 'campscapes': Palestinian refugee camps and informal settlements in Beirut” Political Geography 44 9-18 
This is the accepted version of an article published by Sage in Environment and Planning D: Society and Space Vol. 34 (4), 583-600. Published version available from: https://doi.org/10.1177/0263775815623538

Accepted version downloaded from SOAS Research Online: http://eprints.soas.ac.uk/22575/ under licence CC-BYNC 4.0 International

McMahon D, 2006 The Pursuit of Happiness: A History from the Greeks to the Present (Allen Lane, London)

Menoret P, 2014 Joyriding in Riyadh: Oil, Urbanism, and Road Revolt (Cambridge University Press, Cambridge)

Merabet S, 2014 Queer Beirut (University of Texas Press, Austin, TX)

Mulvey L, 1975, "Visual Pleasure and Narrative Cinema” Screen 16 6-18

Phadke S, Khan S, and Ranade S, 2011 Why Loiter? Women and Risk on Mumbai Streets (Penguin Books, New Delhi)

Reed I, 1998, "Black Pleasure - an Oxymoron" Soul: Black Power, Politics, and Pleasure Eds Guillory M, Green RC (New York University Press, New York, NY) pp 169-171

Rojek, C, 1993, Ways of Escape: Modern Transformations in Leisure and Travel (Palgrave Macmillan, Basingstoke)

al-Saadi Y, 2014, "Daliyeh and the ongoing struggle for Beirut's public spaces" Al-Akbbar 7 May, http://english.al-akhbar.com/node/19679

Sawalha A, 2010 Reconstructing Beirut: Memory and Space in a Postwar Arab City (University of Texas Press, Austin, TX)

Scobey D, 1992, "Anatomy of the promenade: the politics of bourgeois sociability in nineteenthcentury New York." Social History 17 203-227

Taraki L, 2008, "Enclave Micropolis: The Paradoxical Case of Ramallah/Al-Bireh" Journal of Palestine Studies 37 6-20

Van Doorn N, 2013, “Architectures of 'the good life': queer assemblages and the composition of intimate citizenship" Environment and Planning D: Society and Space 31 157-173

Verkaaik O, 2004 Migrants and Militants: Fun and Urban Violence in Pakistan (Princeton University Press, Princeton, NJ)

Weeks K, 2011 The Problem with Work: Feminism, Marxism, Antiwork Politics, and Postwork Imaginaries (Duke University Press, Durham, NC)

Wehbe M, 2014, "Post-Daliyeh: Hariri family eyes Beirut's last public beach Ramlet al-Baida" AlAkhbar 5 September, http://english.al-akhbar.com/node/21399

Zbeeb M, 2012a, "Public Property... for the Rich Only" Al Akbbar 2 October, http://english.alakhbar.com/node/12788

---. 2012b, "Where to Find Lebanon's Worst Seafront Violations" Al Akhbar 10 December, http://english.al-akhbar.com/node/14309 